\title{
The Investors Reaction to the Disclosure of Key Audit Matters: Empirical Evidence from Jordan
}

\author{
Mohammad Abdullah Fayad Altawalbeh ${ }^{1}$, Mohammad Eid Sleem Alhajaya ${ }^{1}$ \\ ${ }^{1}$ Business Faculty, Tafila Technical University, Tafila, Jordan \\ Correspondence: Dr. Mohammad Abdullah Fayad Altawalbeh, Business Faculty, Tafila Technical University, \\ Tafila, Jordan. E-mail: Tawalbeh@ttu.edu.jo
}

Received: December 26, 2018

Accepted: January 29, 2019

Online Published: February 1, 2019

doi:10.5539/ibr.v12n3p50

URL: https://doi.org/10.5539/ibr.v12n3p50

\begin{abstract}
This study aims to examine the investors reaction to the disclosure of key audit matters (KAMs) as mandated by ISA701, the study's sample consisted of all the (195) public shareholding companies listed in Amman Stock Exchange (ASE) as at the end of 2017, and through which we have conducted a manual content analysis to tracing the auditor practices in reporting KAMs, the final sample consisted of (128) public shareholding companies and for which we used the event study test to examine the study hypothesis, results revealed that the disclosure of KAMs has significantly affected the investors decisions measured by the abnormal trading volume, Our findings suggest that the mandating of KAM's disclosure has informational value to the investors.
\end{abstract}

Keywords: key audit matters, international standards on auditing, audit report, Amman stock exchange

\section{Introduction}

The intention of general purpose financial reports is to provide useful information to the interested users (IASB, 2010, OB2). On the other hand, the objective of the external auditor is to form a technical opinion on whether the financial statements are free from material misstatement (ISA200, Para: 11), forming the opinion requires compliance with international auditing standards, which require continuous development to cope with changes in business environment and users needs to enhance the quality of information and to achieve the objective of financial reporting. Years ago the message of auditor's report has been questioned and become symbolic in its value (Manoel \& Quel, 2017), In managing the issue above, standards setters bodies e.g. PCAOB, IAASB, FRC, have been revised the form and content of the auditor's report in order to rebuild the user's confidence and to meet the capital market demand for high quality audit ( li, 2017), as a result of the revising process, the IASB proposed a new audit standard (ISA 701) that requires auditors to disclose key audit matters in the audit report, the main objective is to enhance the communication value of auditor's report. The aim of this paper is to investigate the impact of the disclosure of key audit matters on the investor's decisions, in order to do so, we examined the Jordanian market reaction to the announcements of KAMs, the results show that the Jordanian market reacts differently in response to the disclosure KAMs, therefore, we conclude that KAMs disclosure have information content to the investors. The remainder of this study is organized as follows; in the second section we introduce the ISA701, in the third section we present Jordanian statutory framework and practices, in section four the literature review, in section five the study objectives and hypothesis, the study problem and originality in section six, section seven and eight were devoted to the study methodology and results respectively, finally, we present conclusion, limitations and recommendations in section nine.

\section{International Standard on Auditing (1SA701)}

The International Auditing and Assurance Standards Board (IAASB) is an independent, global, standards-setting body that serves the public interest by strengthening the quality of practices around the world to enhance public confidence in the global audit and assurance profession. The (IAASB) believes that the disclosure of key audit matters in the auditor's report will improve the quality of information and the communicative value of the auditor's report (IAASB, 2011, Para. 2.3). This was reflected in the issuance of ISA701"Communicating Key Audit Matters " which was published in January 2015, and is effective for the audit of financial statements for the periods ended or after December 2016 (IAASB, 2015, paragraph 8), The key audit matters defined as those matters that in the auditor's judgment were most important in conducting an audit of financial statements. Key audit matters are selected from issues that are reported to those charged with governance (IAASB, 2015, Para. 8). 
Interested Users of financial reports are concerned about significant judgments conducted by the auditor in forming his professional opinion, The main purpose of reporting key audit matters is to enhance the communicative value of the auditor's report by reducing information asymmetry about the audit process, reporting key audit matters is expected to provide additional information to the users to assist them understanding those matters, and may also provide users a basis to engage with management and those charged with governance (ISA701).

In order to determine whether a matter is KAM or not, auditors should consider the matters that require significant auditor attention in performing the audit, including: (a) Areas identified as significant risks or; (b) Significant auditor judgments relating to areas in the financial statements that involved significant management judgment, including accounting estimates that have been identified as having high estimation uncertainty , (c) The effect on the audit of significant events or transactions that occurred during the period (IAASB,2015,para9), in addition, ISA701 requires auditors to describe each key audit matter in a separate section and to clarify the reason why it was considered of most significance and how it was addressed (IAASB,2015,para13). However, the standard does not include specific requirements about the number or size of KAM's.

Jordanian companies' law no.22 of 1997 and its amendments to no.30 of 2018 require full adoption of IFRS as released by IASB. The law requires all listed companies to have annual statutory audit except for limited and general partnerships whose capital is less than 100000 JDs. The accountancy Law No. 73 of 2003 allows the Jordanian Association of Certified Public Accountant to recommend auditing standards to be adopted by the Higher Committee of the Accountancy Profession which in turn has adopted all international auditing standards as released by the IAASB.

\section{Literature Review}

Previous studies have examined the communicative value and market reaction towards the release of the independent auditor's report that are prepared in accordance with ISAs,part of these studies have addressed the expanded audit report including the disclosure of KAMs as required by ISA 701; in UK, Reid (2015) examined Whether new disclosure requirements have informative value to investors, overall results show that extended required disclosure provide new and useful information to investors and help in reducing information asymmetry.

In UK also, Gutierrez et.al., (2018) investigated the impact of the expanded auditor's report as required by the Financial Reporting Council (FRC) on the decision usefulness and if there is any indirect effects on audit quality, the study covered four years around the disclosure of the new audit report, the results found that the new audit report has no significant impact on the investor's decisions or on audit quality. In UK also, Lennox et.al, (2018) investigated the impact of the disclosure of the material misstatement risk that had the highest effect in formulating the audit strategy by the auditor, this disclosure became required by the financial reporting council (FRC) on or after 2013 the sample consisted of 488 company listed on London Stock Exchange, results of the study revealed that the disclosure of material misstatement risk does not has informative value to investors. In Newzealand Bradbury e.tal, (2018) examined the impact of KAMs on audit effort, audit quality and on investors decisions, audit effort was measured by audit fees and audit delay, audit quality was measured by abnormal accruals, the results revealed that the disclosure of KAMs has no incremental impact the results also found that investors and auditors price KAMs into audit fees and stock prices.

The study of Köhler, et.al, (2016) examined the communicative value related to the disclosure of KAM in the auditor's report as requested by ISA 701. In addition to non-professional investors, the study also considered professionals investors, the study examined the effect of goodwill impairment in the KAM section, the study's findings showed that if goodwill impairment is led by small changes in key assumptions then the professional investors perceived this situation to be significantly better compared to goodwill impairment that led by large changes in key assumptions. On the other hand, the results revealed that for non-professional investors KAM does not have communicative value.

Carver et.al, (2017) investigated whether the disclosure of critical audit matters (CAM) in the auditor's report_as required by the Public Company Accounting Oversight Board (PCAOB)_ would affect the readability of the auditor's report that perceived by experienced, non-professional investors, and the information content of disclosing CAM the results revealed that the disclosure of CAM s negatively affect the readability of the audits report, and have a limited effect on the informational content for investors.

In china, li (2017)examined the expected benefits of disclosing KAMs that are required by ISA 701. The researcher analyzed 84 external auditors' reports of Chinese listed companies. The result shows that the 
disclosure of KAMs had little impact and the additional information added to the auditor's report is symbolic in nature rather than informative.

In France, Bedard et. al, (2014) tested the effect of disclosure of assessment on financial market reactions. The study analyzed 953 financial reports. The study reveals that there was no effect of the disclosure of assessment on investor decisions.

In Jordan, the study conducted by Althonaibat et.al, (2008)aimed at analyzing the opinions of the external auditors and the financial managers of the Jordanian public shareholding companies about their acceptance of the amendments introduced by the ISA 700 on the external auditor's report. The results showed that the amendments were accepted to varying degrees by the external auditors and the financial managers. The results also showed significant differences between their opinions regarding the impact of these amendments on the expectations gap. in Jordan also, Khadash, (2011) examined the role of the amendments required by ISA 700 in managing the expectations gap. It also examined the importance of adding some other information to the auditor's report.The researcher designed and distributed a questionnaire to auditors, investors and academics. The study found that the amendments to the auditor's report contributed in managing the expectations gap from the view point of the study sample.

\section{Study Objectives and Hypothesis}

The purpose of this study is to examine the impact of the disclosure of KAMs _as required by ISA701_on the investor's decisions. In another word, this study attempt to investigate the information content results from the application of ISA 701.the study also aims to analyze the practices of applying the requirements of ISA 701 in Jordan by collecting and analyzing the financial reports of the of public shareholding companies listed on ASE.

The reaction to disclosure of KAMs still arbitrary, one view that KAMs is expected to reduce the information asymmetry and provide useful information to the users, if this the case, the capital market will react to the disclosure of KAMs Zhang et.al,(2016), as a result the hypothesis of the study will be as follows:

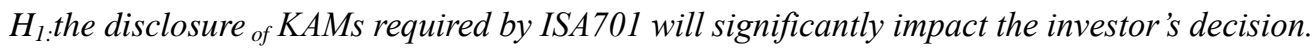

\section{Study Problem and Originality}

According to the IAASB, the launch of the revised IAS701 is a result of the financial statements users call for further firm-specific information to be included in the auditor's report (IAASB, 2015). The Jordanian Companies Law in Article 192 oblige the public companies to elect one or more external auditor, the main objective of the audit is to enhance the confidence of the users of the financial statements with the data contained in them (ISA200, Para. 3). In Jordan, as a developing country that adopts international auditing standards, the new ISA 701 has been implemented as on December 15, 2016. -to our knowledge- this study is the first in Jordan to collect and analyze the practices and contents of the implication of ISA 701.

\section{Methodology}

We have compiled and analyzed a total of 195 audit reports for 2016; this includes all public shareholding companies listed on ASE to assess the practices of the Jordanian External Auditor in disclosing key audit matters. Table (1) shows the number of audit reports analyzed by sector.

Table 1 . Number of financial reports analyzed by sector

\begin{tabular}{lccccccc}
\hline Industry & banks & insurance & Financial services & Real state & service & manufacturing & Total \\
\hline N. reports & 15 & 20 & 31 & 34 & 46 & 49 & 195 \\
\hline
\end{tabular}

Table 2 summarizes the key audit matters included in the auditor's report for 2016: 
Table 2. Summary of KAMs by sector

\begin{tabular}{|c|c|c|c|c|c|c|c|c|}
\hline KAM 's topic & $\begin{array}{l}\text { Manufacturing } \\
\text { sector }\end{array}$ & $\begin{array}{l}\text { Banking } \\
\text { sector }\end{array}$ & $\begin{array}{l}\text { Insurance } \\
\text { sector }\end{array}$ & $\begin{array}{c}\text { Service } \\
\text { sector }\end{array}$ & $\begin{array}{l}\text { Real } \\
\text { estate } \\
\text { sector }\end{array}$ & $\begin{array}{c}\text { Financial } \\
\text { services }\end{array}$ & Total & $\begin{array}{c}\text { KAMs } \\
\text { percentage } \\
\text { by topic }\end{array}$ \\
\hline provisions & 16 & 15 & 31 & 9 & 9 & 1 & 81 & $26 \%$ \\
\hline Revenue & 6 & 7 & 17 & 13 & 3 & 4 & 50 & $16 \%$ \\
\hline Inventory & 22 & & & 3 & 1 & 1 & 27 & $9 \%$ \\
\hline $\begin{array}{l}\text { property } \\
\text { investment }\end{array}$ & & & & 5 & 17 & 2 & 24 & $8 \%$ \\
\hline Evaluation & 4 & 7 & 7 & & 1 & 3 & 22 & $7 \%$ \\
\hline Receivables & 16 & 2 & 2 & & & & 20 & $6 \%$ \\
\hline PPE & 6 & 2 & 1 & 6 & 4 & 1 & 20 & $6 \%$ \\
\hline Goodwill & 2 & 1 & 4 & 5 & 2 & & 14 & $4 \%$ \\
\hline Fair value & & & 1 & 2 & 2 & 7 & 12 & $4 \%$ \\
\hline $\begin{array}{l}\text { Investments in } \\
\text { related parties }\end{array}$ & 5 & 2 & & 1 & & & 8 & $3 \%$ \\
\hline $\begin{array}{l}\text { contingent } \\
\text { liabilities }\end{array}$ & 1 & & & 4 & 2 & & 7 & $2 \%$ \\
\hline sales & 3 & & & 2 & 2 & & 7 & $2 \%$ \\
\hline $\begin{array}{l}\text { Financial } \\
\text { instruments }\end{array}$ & 2 & 4 & & & & & 6 & $2 \%$ \\
\hline $\begin{array}{l}\text { projects under } \\
\text { construction }\end{array}$ & & & & 2 & 3 & & 5 & $2 \%$ \\
\hline TAX asset & & & 4 & & & & 4 & $1 \%$ \\
\hline Share capital & 1 & & 1 & 1 & & 1 & 4 & $1 \%$ \\
\hline Acquisition & & 1 & & & & & 1 & $0 \%$ \\
\hline Investments & & & & & & 1 & 1 & $0 \%$ \\
\hline IT system & & 1 & & & & & 1 & $0 \%$ \\
\hline leases contracts & & & & 1 & & & 1 & $0 \%$ \\
\hline loans & & & & & 1 & & 1 & $0 \%$ \\
\hline biological assets & 1 & & & & & & 1 & $0 \%$ \\
\hline total & 85 & 42 & 68 & 54 & 47 & 21 & 317 & \\
\hline $\begin{array}{l}\text { KAM's } \\
\text { percentage by } \\
\text { industry }\end{array}$ & $27 \%$ & $13 \%$ & $21 \%$ & $17 \%$ & $15 \%$ & $7 \%$ & & \\
\hline
\end{tabular}

Depending on Table 2 we mention the following observations: The manufacturing sector ranked first in the volume of KAMs, which constituted $27 \%$ of the total KAMs. The insurance sector came second with $21 \%$ of total KAMs, followed by the services sector with $17 \%$. The real estate sector ranked fourth with $15 \%$, banking with $13 \%$ and financial services with 7\%. From the perspective of KAMs topics, we noticed that provisions were the most reported topic with $26 \%$ of total reported KAMs, $38 \%$ of provisions topic was reported by insurance sector, while $19 \%$ and $18.5 \%$ arise in the audit reports of manufacturing sector and banking sector respectively, the current study believes that, the auditors focus on provisions might be due to the inherent risk of this topic as provisions increase the management ability to manipulate accounting numbers. Revenue was the second topic reported by auditors with $16 \%$ of total KAMs, about $34 \%$ of revenue topic was reported in the insurance sector while $26 \%$ was reported in the services sector. The third topic was inventory with $9 \%$ of total KAMs, $81 \%$ of inventory topic was reported by manufacturing sector.

\subsection{Sample and Data}

The study population consists of all the public shareholding companies listed on ASE during the period of study and for which the required data available. However, our final sample consisted of 128 public shareholding companies, out of which 16 companies did not include any KAMs in its audit report. We indicated 1 if the company disclosed KAMs and 0 otherwise. This study mainly based on obtaining the necessary data through financial reports published on the ASE website.

\subsection{Study Model}

To achieve the study objectives we used an empirical model that enables to examine the investor's response to the disclosure of KAMs. Following (Gutierrez et.al,2018), We measured the investor's response through the absolute value of abnormal trading volume to cover the event date and the days of the event window which we determined to be 20 days before day 0 and 10 days after. If the disclosure of KAMs implies investor response, then KAMs should show positive coefficient. We control for the company size measured by the natural logarithm of total assets (Ln-T. Assets), return on assets (ROA),market to book value ratio (MB), Leverage (LEV), whether the company is enlisted in the first market or not (CLASS) we indicated 1 if the company is enlisted in 
the first market and 0 otherwise.

$$
|A B T V|=\beta 0+\beta 1 K A M+\beta 2 \text { Ln-T. Assets }+\beta 3 R O A+\beta 4 M B+\beta 5 L E V+\beta 6 \text { Class }
$$

\section{Results}

\subsection{Descriptive Statistics}

Table 3 shows descriptive statistics for the study dependent variable; the abnormal trading volume (ABTV), which is measured by the natural logarithm of (ABTV) during the event window. The average of the ABTV for the study sample amounted 3.84 logarithms (equivalent to JD 57933.9) which represent about $75 \%$ of the average trading volume for the sample during 2017, which indicates a substantial value of abnormal trading volume during the event window.

Table 3.Descriptive Statistics for the Dependent Variable: Abnormal Trading Volume

\begin{tabular}{cc}
\hline & $\begin{array}{c}\text { ABTV } \\
\text { (natural logarithm) }\end{array}$ \\
\hline Mean & 3.8433 \\
Median & 3.8783 \\
Maximum & 6.6108 \\
Minimum & 1.0414 \\
Std. Dev. & 0.8781 \\
Skewness & -0.2412 \\
Kurtosis & 3.3534 \\
Jarque-Bera & 1.9074 \\
Probability & 0.3853 \\
observations & 128 \\
Cross sections & 128 \\
\hline
\end{tabular}

Table 4 presents the descriptive statistics of the independent variable (KAMs) and the controls variables used:

1. The average of KAMs disclosed by the sample is 0.875 , which is close to one, indicating that most of our sample companies have disclosed KAMs.

2. Company Size (LNTA): the average size of sample companies amounted 7.36 logarithms (about JD 22.95 million), and ranged from 3.95 to 9.10 logarithm, with a standard deviation of 0.71 , which indicates the existence of significant differences in size among the sample.

3. Return on Assets (ROA): the average ROA for the sample was negative and reached to (-3.4\%), indicating a poor performance for those companies during the year 2017. Nevertheless, some companies performed very well as the maximum ROA reached (36.1\%) while some companies achieved high losses as the minimum ROA reached (-195.3\%). The standard deviation amounted $46.98 \%$, which reflects the significant differences in the profitability of the sample.

4. Market to Book value (MB): the average of market to book value ratio amounted 1.54, which reflects that the market value for the companies' shares is higher than their book value by about $50 \%$. The MB ratio ranged from 0.17 to 44.5 times, with a standard deviation of 4.1, indicating the significant difference among the sample in terms of MB ratio.

5. Leverage Ratio (LEV): the average leverage ratio for the sample reached $29.7 \%$, indicating a moderate borrowing behavior for those companies and a relatively acceptable level of leverage. However, the average leverage ratio ranged from $0.1 \%$ to $93.0 \%$, with a standard deviation of $22.3 \%$, indicating significant differences in debt structure.

Table 4. Descriptive Statistics for Independent and Control Variables

\begin{tabular}{|c|c|c|c|c|c|c|}
\hline & KAM & LNTA & $\mathrm{ROA}$ & $\mathrm{MB}$ & LEV & CLASS \\
\hline Mean & 0.8750 & 7.3608 & -3.4407 & 1.5398 & 29.6740 & 0.2677 \\
\hline Median & 1.0000 & 7.3620 & 1.7400 & 0.8750 & 27.3550 & 0.0000 \\
\hline Maximum & 1.0000 & 9.0946 & 36.0700 & 44.4600 & 93.0100 & 1.0000 \\
\hline Minimum & 0.0000 & 3.9500 & -195.2800 & 0.1700 & 0.1100 & 0.0000 \\
\hline Std. Dev. & 0.3320 & 0.7073 & 46.9824 & 4.0683 & 22.2866 & 0.4428 \\
\hline Skewness & -2.2678 & -0.9055 & -8.9454 & 9.4473 & 0.9145 & 1.0535 \\
\hline Kurtosis & 6.1429 & 7.1667 & 88.5660 & 98.7038 & 3.2655 & 2.1176 \\
\hline Jarque-Bera & 16.3946 & 110.0868 & 40.3300 & 50.1700 & 18.2175 & 27.8283 \\
\hline Probability & 0.0000 & 0.0000 & 0.0000 & 0.0000 & 0.0001 & 0.0000 \\
\hline observations & 128 & 128 & 128 & 128 & 128 & 128 \\
\hline Cross sections & 128 & 128 & 128 & 128 & 128 & 128 \\
\hline
\end{tabular}


Table (5) presents the Pearson correlation matrix for all variables. The correlations between dependent variable and independent variables were positive. There is a positive correlation of 0.219 between the dependent variable, ABTV, and the independent variable, KAM, indicating that higher abnormal trading volume is associated with KAMs. The correlation between ABTV and LNTA was 0.229, indicating that the larger the company, the higher the abnormal trading volume. Correlations between ABTV, ROA and LEV ranged from 15\%-16\%. but ABTV and other independent variables show a weak inter correlations indicating the absence of multicollinearity.

Table 5. Pearson Correlations Matrix

\begin{tabular}{|c|c|c|c|c|c|c|c|}
\hline & ABTV & KAM & LNTA & ROA & MB & LEV & CLASS \\
\hline ABTV & 1.000 & & & & & & \\
\hline KAM & 0.219 & 1.000 & & & & & \\
\hline LNTA & 0.229 & 0.204 & 1.000 & & & & \\
\hline ROA & 0.150 & 0.245 & 0.470 & 1.000 & & & \\
\hline MB & 0.082 & 0.021 & -0.248 & -0.315 & 1.000 & & \\
\hline LEV & 0.158 & 0.069 & 0.308 & 0.038 & 0.284 & 1.000 & \\
\hline CLASS & 0.025 & 0.176 & 0.304 & 0.194 & 0.019 & -0.094 & 1.000 \\
\hline
\end{tabular}

7.2 Regression Results

Table 6 presents the results of panel data regression that investigates the effect of the disclosure of KAMs and other variables on the level of abnormal trading volume. Based on the results, we notice that all independent variables were significant at $1 \%$ level. The adjusted R-squared for the model amounted $83.6 \%$, indicating that the independent variables explain high proportion of the change in abnormal trading volume, while F-statistic and its probability indicate the model goodness of fit.

Following prior literature, We expect that relevant information to the investors and KAMs disclosur provides , consequently will impact their trading decisionconsistent with our prediction, KAMs show positive and significant coefficients, which indicates that the disclosure of KAMs seems to result in abnormal trading volume. Our results are consistent with Reid et.al (2015) who found that the expanded audit report is informative to the investors in UK, our findings are also consistent with the view that additional disclosure in the auditor's report would enhance the informational value of the auditor's report (FRC 2015: page 57; Manson and Zaman 2001; church et.al 2008), and also consistent with the Association of Chartered Certified Accountants review report (2018); which found that the disclosure of KAMs is not only useful to the investors but also contribute to better governance ,better audit quality and better corporate reporting. Our findings suggest that KAMs disclosure have a significant effect on investors' behavior and decision, and continue to indicate the value of additional information included in the auditor's report. The results in table 6 also indicate appositive and significant coefficient on the company's size (LNTA), Return on assets (ROA), Market to book value ratio (MB) and Leverage ratio (LEV), these results are consistent with Lennox et.al, (2018), we believe that large, more profitable, complex and more attractive companies are highly exposed to abnormal trading volume .However, market class (CLASS) was negative and significant, indicating that companies enlisted in the first market have less abnormal trading volumes.

Table 6. Regression Results for the Dependent Variable (ABTV)

\begin{tabular}{rccc}
\hline Variable & Coefficient & t-Statistic & Prob. \\
\hline C & 2.4085 & 28.5595 & 0.0000 \\
KAM & 0.4846 & 7.4537 & 0.0000 \\
LNTA & 0.1223 & 16.9740 & 0.0000 \\
ROA & 0.0072 & 10.0818 & 0.0000 \\
MB & 0.0801 & 10.2446 & 0.0000 \\
LEV & 0.0018 & 6.8650 & 0.0000 \\
CLASS & -0.2140 & -8.8307 & 0.0000 \\
\hline R-squared & Regression Statistics & & \\
Adjusted R-squared & & 0.8434 & \\
S.E. of regression & & 0.8357 & \\
F-statistic & & 0.8438 & 108.6318 \\
Prob. (F-statistic) & & 0.0000 & \\
\hline
\end{tabular}

* Using White (1980) heteroscedasticity standard errors and covariance.

\section{Conclusions}

This study aims at investigating the investor's reaction - measured by abnormal trading volume- to the disclosure of KAMs reported by Jordanian public shareholders companies. we employed KAMs as the independent variables and control for company size, Return on assets, market to book value ratio, leverage ratio and market 
class. Manually content analysis shows that manufacturing sector was ranked first with respect to the reported KAMs volume, while provisions were the most reported topic. The results of the regression analysis which Based on a final sample of 128 Jordanian public shareholding companies find evidence that KAMs disclosure -as required by ISA701- has a significant impact on investor's decisions, indicating that the application of ISA 701 benefit investors and provide useful information. This finding supports the view that the disclosure of Key audit matters have a significant effect on investors behavior. This study does not claim to be the comprehensive empirical study of KAMs subject but rather to provide relevant evidence from the developing countries context which is expected to add to the existing debate on the release of ISA701. this study might also suffer from the limitations of event studies (chen,2017), for example; the event date cannot be determined accurately, on the other hand, calculating the abnormal trading volume might persuade bias, future researches are recommended to include additional firm-years observations, and to investigate the effect of KAMs disclosure on audit quality.

\section{References}

Althuneibat, A. et al (2008). The Effect of Application of International Auditing Standard No. (700) as amended on the auditor's report in narrowing the expectations gap from the point of view of the Palestinian investor. The Jordanian Journal of Business Administration, 4(3), 2008.

Association of Chartered Certified Accountants (ACCA). (2018). Key audit matters: unlocking the secrets of the audit, a review report, available at:

https://www.accaglobal.com/in/en/professional-insights/global-profession/key-audit-matters.html, accessed 18 July 2018.

Bédard, J., Gonthier-Besacier, N., \& Schatt, A. (2014). Costs and benefits of reporting Key Audit Matters in the audit report: The French experience. International Symposium on Audit Research. Available at: http://documents.escdijon.eu/pdf/cig2014/ACTESDUCOLLOQUE/BEDARD_GONTHIER_BESACIER_S CHATT.pdf

Bradbury, M. E., \&Almulla, M. (2018). Auditor, Client, and Investor Consequences of the Enhanced Auditor's Report. https://doi.org/10.2139/ssrn.3165267

Carver, B. T., \& Trinkle, B. S. (2017). Nonprofessional Investors' Reactions to the PCAOB's Proposed Changes to the Standard Audit Report. https://doi.org/10.2139/ssrn.2930375

Chen, C. (2017). Limitations to Event Studies and How They Apply. http://dx.doi.org/10.2139/ssrn.2982219

Church, B. K., S. M. D., \& S. A. McCracken. (2008). The auditor's reporting model: A literature overview and a research synthesis. Accounting Horizons, 22(1), 69-90.https://doi.org/10.2308/acch.2008.22.1.69

Financial Reporting Council (2015). 'Extended auditor's reports - A review of experience in the first year'. <https://www.frc.org.uk/news/ march-2015/frc-finds-good-take-up-of-new-auditor-reporting-re>,accessed 17 march 2018.

Gutierrez, E. F., \& Minutti-Meza, M., Tatum, K., \& Vulcheva, M. (2018). https://www.ifac.org/about-ifac/membership/country/jordan, accessed 21 July 2018

IAASB. (2015), Auditor reporting-KAM, working group.

IFRS. (2010). Conceptual Framework for Financial Reporting 2010. Available at: http://www.ifrs.org/News/Press-Releases/Documents/ConceptualFW2010vb.pdf,Accessed 21/august/2018.

International Standard on Auditing 200. (2017). Available at: http://www.ifac.org/system/files/downloads/a008-2010-iaasb-handbook-isa-200.pdfAccessed20/July/2018.

International Standard On Auditing 701. (2017). Available at: http://www.ifac.org/system/files/downloads/a008-2010-iaasb-handbook-isa-200.pdfAccessed13/April/2018.

Khadash, H., Al-Zawawi, I., \& Nassar, M. (2011). Effect of Amendments to the International Standard on Auditing" (700) and the report of the auditor on narrowing the expectations gap Auditors and financial statements preparers in financial sector companies and institutional investors. The Jordanian Journal of Business Administration, University of Jordan, 7(4), 594-62.

Köhler, A., Ratzinger, S., Nicole, V. S., \& Theis, J. (2016). The Effects of Key Audit Matters on the Auditor's Report's Communicative Value: Experimental Evidence from Investment Professionals and Non-Professional Investor. https://doi.org/10.2139/ssrn.2838162

Lennox, C. S., Schmidt, J. J., \& Thompson, A. (2018). Is the expanded model of audit reporting informative to investors? Evidence from the UK. 
Li, H. (20178). The benefit of adding key audit matters to the auditing report, Advances in Economics, Business and Management Research, volume 49, 2nd International Conference on Education, Management Science and Economics.

Manoel, J., \& Quel, L. F. (2017). Innovation in the international standards for the new independent audit report. Journal on Innovation and Sustainability, 8(1), 130-143.

Manson, S., \& M. Zaman. (2001). Auditor communication in an evolving environment: Going beyond SAS 600 auditor's report on financial statements. British Accounting Review, 33(2), 113-136. https://doi.org/10.1006/bare.2001.0157

Reid, L., Carcello, J. V., Li, C., \& Neil, T. (2015). Are auditor and audit committee report changes useful to investors? Evidence from the United Kingdom. Working paper, University of Pittsburgh and University of Tennessee. https://doi.org/10.2139/ssrn.2637880

Zhang, J. X., Cai, Y. D., \& Liu, W. H. (2016). Improvement of Standard Audit Report, Relationship between Management and Auditors and Willingness of Managers to Communicate - An Experimental Evidence. Audit Research, 3, 77-83, 2016. (In Chinese).

\section{Copyrights}

Copyright for this article is retained by the author(s), with first publication rights granted to the journal.

This is an open-access article distributed under the terms and conditions of the Creative Commons Attribution license (http://creativecommons.org/licenses/by/4.0/). 